\title{
Ecological Assessment of Lakes with Different Salinity in Southern Ob-Irtysh Interfluve Using Macrozoobenthos — Based Bioindication
}

\author{
Dmitry Bezmaternykh, Olga Vdovina \\ Institute for Water and Environmental Problems, \\ Siberian Branch of the Russian Academy of Sciences, Barnaul, Russia \\ Email: bezmater@iwep.ru
}

\begin{abstract}
The ecological assessment (2007-2011) of five lake systems (i.e. Chany, Karasuk, Burla, Kulunda, Kasmala) situated in the south of the Ob-Irtysh interfluve was made based on the analysis of the data on macrozoobenthos composition, structure and abundance. Mineralization of the studied lakes was within $0.33-140 \mathrm{~g} / \mathrm{dm}^{3}$. To analyze the lakes with salinity up to $3 \mathrm{~g} / \mathrm{dm}^{3}$, it was recommended to use the Flemish multimetric index, the Shannon index of species diversity and the Goodnight and Whitley oligochaeta index. For the lakes with salinity more than $3 \mathrm{~g} / \mathrm{dm}^{3}$ the formula for calculation of probable macrozoobenthos biomass that could be at the absence of inhibitory effect of salinity was proposed. Using the calculated potential biomass of macrozoobenthos, one can define a real trophic status of the lakes.
\end{abstract}

Keywords: Macrozoobenthos, lakes, salinity, ecological factors, Ob-Irtysh interfluve.

\section{Introduction}

The study area of the southern Ob-Irtysh interfluve covers the Baraba and Kulunda lowlands as well as the Ob Plateau located in the south of West Siberian Plain [1]. Numerous lakes of the southern ObIrtysh interfluve are characterized by water shallowness, unstable water level, a wide range of dissolved salts, mean or high trophic level, and suffocation phenomena [2]. Agricultural nature management is typical for the lakes' catchments. Some water bodies of this region are used for recreation purposes, the others (rather rarely) for water consumption and drainage [3]. Trading of aquatic bioresources is widely spread here as well [4].

Zoobenthos is a community of animals dwelling at the water/substrate boundary [5]. Organisms exceeding $2 \mathrm{~mm}$ in size are referred to macrobenthos. It is common knowledge that macrozoobenthos depends on ecological state of reservoirs, i.e. their water quality and trophic level, for assessment of which various methods of biological indication (mainly developed for freshwater objects and watercourses) are applied. With salinity increase species diversity decreases that brings to the change in benthic communities structure and the reduction in their biomass. Obviously the use of freshwater indices for the assessment of saline lakes is inappropriate [6]. Sub-haline lakes are transitional between freshwater and saline ecosystems. To establish a clear boundary between them is hardly possible; generally, the increased salinity effect on aquatic ecosystems occurs at water salinity $>3 \mathrm{~g} / \mathrm{dm}^{3}[7-9]$. Therefore, the analysis of the ecological state of lakes and the assessment of mineralization effect on biotic indices were conducted separately for waters with different salinity, i.e. 1) $>3 \mathrm{~g} / \mathrm{dm}^{3}$ and 2) $<3$ $\mathrm{g} / \mathrm{dm}^{3}$.

\section{Material and Methods}

Within the framework of the complex limnological survey (2007-2011), we investigated benthic invertebrate communities from 41 lakes of five lake systems (Chany, Karasuk, Burla, Kulunda, Kasmala) of the southern Ob-Irtysh interfluve located in the steppe and forest-steppe zones of West Siberia (Fig. 1). Total mineralization of the studied lakes was within $0.33-140.0 \mathrm{~g} / \mathrm{dm}^{3}$. Hydrochemical characteristics of lakes were presented in papers [10-13]. 


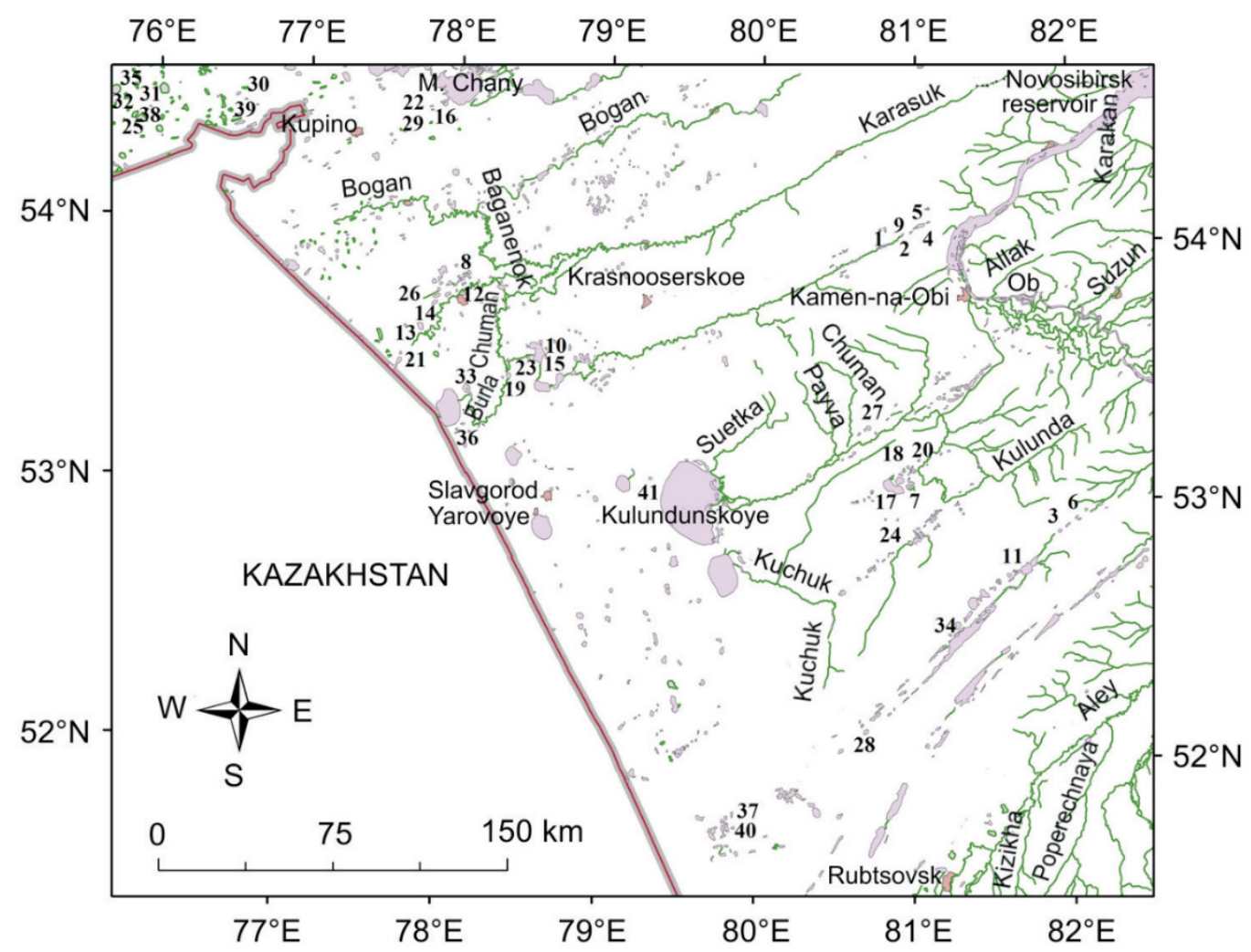

Figure 1. Investigated lakes of the southern Ob-Irtysh interfluve. Salinity $<3 \mathrm{~g} / \mathrm{dm}^{3}: 1-$ Pryganskoye; $2-$ Verkhneye; 3 - Ledoreznoye; 4 - Nizhneye; 5 - Bol. Pustynnoye; 6 - Mel'nichnoye; 7 - Batovoye; 8 - Krivoye (Karasuk River basin); 9 - Bol'shoye; 10 - Mal. Topol'noye; 11 - Bol. Ostrovnoye; 12 - Titovo; 13 - Astrodym; 14 - Kusgan; 15 - Khomutinnoye; 16 - Fadikha; 17 - Kabanye; 18 - Mostovoye; 19 - Peschanoye; 20 - Chernakovo; 21 - Stud'enoye; 22 - Kotlenok; 23 - Khorosheye; 24 - Krivoye (Kulunda River basin); 25 - Dunenok; 26 - Mal. Go'rkoye (Karasuk River basin); 27 - Lena; 28 - Uglovoye; 29 - Shirokaya Kurya; Salinity >3 g/dm ${ }^{3}: 30$ Abushkan; 31 - Fateyevo; 32 - Iliubaysor; 33 - Krivoye (Burla River basin); 34 - Gor'koye (Kasmala River basin); 35 - Gor'koye; 36 - Bol. Topol'noye; 37 - Presnoye; 38 - Levoye Polyanovo; 39 - Chebakly; 40 - Liuskino; 41 Kulundinskoye.

To collect and process the material, we used the standard methods [14]. For instance, qualitative samples were taken by a net or a scraper, quantitative samples - by the Petersen's bottom drag with a sampling area of $0.025 \mathrm{~m}^{2}$ or by the bar drag GR-91 with a sampling area of $0.007 \mathrm{~m}^{2}$. A total of 371 quantitative and 76 qualitative samples were collected and processed.

For ecological assessment of the studied lakes, the following indices were used: Multimetric Macroinvertebrate Index Flanders (MMIF) [15], oligochaeta index (the ratio of Oligochaeta number to total zoobenthos) [16] and the Shanon index of species diversity [17]. When assessing the ecological state of lakes based on the Shannon index, we applied the V. A. Yakovlev scale [18]. Trophic level of the lakes was defined due to the S. P. Kitayev's scale [19]: zoobenthos biomass of $<0.625 \mathrm{~g} / \mathrm{m}^{2}$ corresponded to ultraoligotrophic type of water body; $0.625-1.25$ - to $\alpha$-oligotrophic, $1.25-2.5$ - to $\beta$-oligotrophic, $2.5-$ 5 - to $\alpha$-mesotrophic, $5-10$ - to $\beta$-mesotrophic, $10-20$ - to $\alpha$-eutrophic, $20-40$ - to $\beta$-eutrophic, and > 40 - to hypertrophic one.

The obtained results were statistically processed by means of MS Excel-2013. More detail description of the methods and conditions of sampling was given in our previous works [20-23].

\section{Results and Discussion}

We now direct our attention to the indicators of macrozoobenthos composition and structure in lakes 
with salinity up to $3 \mathrm{~g} / \mathrm{dm}^{3}$ (table 1 ). In water bodies of the Prichanovsk group, the Shannon index of species diversity made up $0.5-2.5$ bits/ind. High values were marked in lakes Kotlenok (2.3) and Shirokaya Kuria (2.5), whereas low ones in - lakes Fadikha and Dunya (0.5 and 1.0, respectively) that is evidence of unfavorable conditions for macrozoobenthos habitation.

In the reservoirs of the Karasuk system, the Shannon index varied in the range of $0.6-3.0 \mathrm{bit} / \mathrm{ind}$. The highest index (3.0), characteristic of clean waters, was revealed in lake Krivoye, and the lowest - in lakes Krotovo (0.9) and Chagan (0.6) that points to the unfavorable environmental situation. For most of water bodies the index ranged as 1.0-1.5 that corresponded to a "moderately polluted" water.

In the Burla lake system, the Shannon index was the highest (from 2.1 to 2.9 bits/ind.) in four reservoirs that is specific for "slightly contaminated" waters. The least value was recorded in lake Bol'shoye (0.6) that is typical for "contaminated" reservoirs. In other Burla water bodies it ranged within 1.0-1.4 and corresponded to a "moderate pollution" of the waters.

Most lakes of the Kulunda system with the Shannon index from 1.0 to 1.5 bits/ind. were referred to the "moderately polluted" ones. The highest index of species diversity was identified in lake Batovoye (3.0) that is characteristic of "pure water", whereas the least - in lake Chernakovo (0.5) that points out to unfavorable for macrozoobenthos conditions.

In lakes Bol. Ostrovnoye, Gor'koye, Mel'nichnoye of the Kasmala system, the Shannon index ranged from 0.8 to 1.2 bits/ind. that is typical for the "moderately polluted" reservoirs. In lakes Ledoreznoye and Uglovoye the index was 0.8 and 0.9 , respectively ("polluted waters").

Oligochaetes were not found in lakes of the Prichanovsk group, and the Goodnight and Whitley oligochaeta index (OI, \%) was equal to zero. The value of this index in the reservoirs of the Karasuk system changed from 0 to $32 \%$ (table 1). In most lakes oligochaetes were not identified. For lakes Astrodym, Krivoye and Titovo the index was below $10 \%$ that corresponds to the first (I) water quality class - "very clean". The highest OI values were revealed in lake Melkoye (32\%) - the second (II) quality class ("clean" water).

In the Burla lake system, the oligochaeta index varied greatly (0-100\%). Lake Topol'noye had maximum values (71-100\%) in its different sites that is characteristic of classes V and VI ("dirty" and "very dirty"). In addition, the unfavorable environmental situation for benthic communities occurred in lakes Peschanoye and Khomutinoye, where OI corresponded to IV and V classes of water quality.

In the Kulunda system, OI values varied in the range of 0-25\%. In the central part of lake Mostovoye, this index corresponded to class II ("pure"). In other water bodies oligochaetes were not identified at all. A similar situation was observed in the Kasmala lake system. For instance, oligochaetes were absent in most lakes. For lakes Ledoreznoye and Mel'nichnoye OI values were low - class I (very"clean").

Thus, the oligochaeta index turned out to be non-informative for the lakes under study because of low oligochaete density. Being unreliable in this case [24], the index can be used in combination with other biological indication methods (at its increased values).

Multimetric Macroinvertebrate Index Flanders (MMIF) for the majority of lakes from the Prichanovsk group is indicative of "bad" and "low" water quality (table 1). In most lakes of the Karasuk system, MMIF index represents "low" water quality. The most favorable conditions for benthos ("fair") prevailed in lakes Astrodym and Titovo (0.5-0.6). The highest MMIF was recorded in lake Krivoye (0.75) - "good" water quality. The situation unfavorable for benthos was marked in lake Chagan (0.15) "bad" water quality.

In the Burla lake system, MMIF varied widely (0.05-0.8). The least MMIF was identified in lakes Bol'shoye, Kaban'ye and Topol'noye that corresponded to a "bad" water quality class. Water quality in most lakes was low (0.30-0.45); a bit higher it was in lakes Nizhneye and Peschanoye (0.55) that points out to their "fair" state. The best conditions existed in shallow lakes Verkhneye (Podvetrennoye) and Pryganskoye (assessed as "good").

Adverse environmental conditions were recorded in lakes of the Kulunda and Kasmala systems, where water quality in the majority of lakes was "bad" and "low" (MMIF =0.1-0.4). The increase in MMIF up to $0.5-0.6$ was observed in lakes characterized by maximal species diversity (Batovoye and Mel'nichnoye) with the waters of "fair" quality. Low water quality of most studied lakes is primarily due to their natural features [25].

Trophic status (calculated by macrozoobenthos biomass according to the S. P. Kitaev) of lakes from the Prichanovsk group varied from a "very low" to a "high" one. Maximal macrozoobenthos biomass was 
observed in lakes Kotlenok and Shirokaya Kurya (table 1); the rest reservoirs were characterized as oligotrophic and mesotrophic reservoirs.

Table 1. Bioindication indices of macrozoobenthos in lakes of southern Ob-Irtysh interfluve with water salinity less than $3 \mathrm{~g} / \mathrm{dm}^{3}$

\begin{tabular}{|c|c|c|c|}
\hline \multicolumn{4}{|c|}{ Ultraoligotrophic } \\
\hline Bol. Gor'koye & 1.0 & 0 & $0.30-1$ \\
\hline Bol. Ostrovnoye & 1.1 & 0 & $0.15-\mathrm{b}$ \\
\hline Lena & 1.5 & 0 & $0.30-1$ \\
\hline Stud'enoye & 1.0 & 0 & $0.30-1$ \\
\hline \multicolumn{4}{|l|}{ Oligotrophic } \\
\hline Bol. Pustynnoye & 2.1 & 0 & $0.30-\mathrm{b}$ \\
\hline Gor'koye & 1.2 & 0 & $0.40-1$ \\
\hline Krivoye & 3.0 & $10-\mathrm{I}$ & $0.75-\mathrm{g}$ \\
\hline Kusgan & 1.4 & 0 & $0.45-1$ \\
\hline Ledoreznoye & 0.8 & $20-\mathrm{I}$ & $0.25-1$ \\
\hline Nizhneye & 2.7 & 0 & $0.55-\mathrm{s}$ \\
\hline Topol'noye & 1.0 & $89-\mathrm{VI}$ & $0.05-b$ \\
\hline Fadikha & 0.5 & 0 & $0.15-b$ \\
\hline Chernakovo & 0.5 & 0 & $0.10-b$ \\
\hline \multicolumn{4}{|c|}{$\alpha$-mesotrophic } \\
\hline Dunya & 1.0 & 0 & $0.25-\mathrm{b}$ \\
\hline Kabanye & 1.1 & 0 & $0.25-1$ \\
\hline Krivoye & 1.0 & 0 & $0.25-1$ \\
\hline Mel'nichnoye & 1.1 & $0.5-\mathrm{I}$ & $0.50-\mathrm{f}$ \\
\hline Uglovoye & 0.9 & 0 & $0.40-1$ \\
\hline Chagan & 0.6 & 0 & $0.15-\mathrm{b}$ \\
\hline \multicolumn{4}{|c|}{$\beta$-mesotrophic } \\
\hline Astrodym & 1.5 & $3-\mathrm{I}$ & $0.60-\mathrm{f}$ \\
\hline Batovoye & 3.0 & 0 & $0.60-\mathrm{f}$ \\
\hline Bol'shoye & 0.6 & 0 & $0.25-\mathrm{b}$ \\
\hline Verkhneye (Podvetrennoye) & 2.9 & 0 & $0.80-\mathrm{g}$ \\
\hline Krotovo & 0.9 & 0 & $0.45-1$ \\
\hline Melkoye & 1.5 & $32-\mathrm{II}$ & $0.35-1$ \\
\hline Mostovoye & 1.4 & $13-\mathrm{I}$ & $0.40-1$ \\
\hline Peschanoye & 1.3 & $28-$ II & $0.55-\mathrm{b}$ \\
\hline Khorosheye & 2.5 & 10 & $0.45-1$ \\
\hline \multicolumn{4}{|c|}{$\alpha$-eutrophic } \\
\hline Kotlenok & 2.3 & 0 & $0.25-\mathrm{b}$ \\
\hline Pryganskoye & 1.1 & 0 & $0.70-\mathrm{g}$ \\
\hline \multicolumn{4}{|c|}{$\beta$-eutrophic } \\
\hline Titovo & 1.0 & $7-\mathrm{I}$ & $0.50-\mathrm{f}$ \\
\hline Khomutinnoye & 1.4 & $48-$ III & $0.30-1$ \\
\hline Shirokaya Kurya & 2.5 & 0 & $0.45-1$ \\
\hline
\end{tabular}

Note: $\mathrm{H}$ - is the Shannon index of species diversity; OI - Goodnight and Whitley oligochaeta index (\%); MMIF Multimetric Macroinvertebrate Index Flanders; I - very clean; II - clean; III - moderately polluted; VI contaminated; g - good; f - fair; l - low; b - bad.

In the Karasuk lake system, macrozoobenthos biomass ranged from a "very low" to a "high" class. The highest macrozoobenthos density and biomass were registered in some sites of lakes Titovo (1.7 th. ind $/ \mathrm{m}^{2}, 29.8 \mathrm{~g} / \mathrm{m}^{2}$ ) and Shkalovo $\left(2.1 \mathrm{th}\right.$. ind. $\left./ \mathrm{m}^{2}, 22.6 \mathrm{~g} / \mathrm{m}^{2}\right)$, which may be ascribed to $\beta$-eutrophic class. The rest lakes from this system were of ultraoligotrophic, oligotrophic and mesotrophic type. 
Trophicity of water bodies from the Burla system considerably varied from ultraoligotrophic to $\beta$ eutrophic one. The best zoobenthos development was recorded in lakes Pryganskoye and Khomutinoye; others were oligotrophic and mesotrophic water bodies.

In the Kulunda system, trophicity generally varied from ultraoligotrophic to $\beta$-mesotrophic as well. In the central part of lakes, trophic level corresponded to oligotrophic $\left(0.1-2.3 \mathrm{~g} / \mathrm{m}^{2}\right)$, while in the coastal zone of some lakes - to $\alpha$-eutrophic class.

Trophicity of the Kasmala system lakes changed from ultraoligotrophic to $\beta$-mesotrophic level. In the central part of lakes it usually ranged from ultraoligotrophic to oligotrophic $\left(0.28-2.5 \mathrm{~g} / \mathrm{m}^{2}\right)$, and in the littoral it reached $\beta$-mesotrophic and $\alpha$-eutrophic level.

In the reservoirs with salinity of $3 \mathrm{~g} / \mathrm{dm}^{3}$ and higher, the bioindication methods provided support for an unfavorable ecological situation (table 2). As it was mentioned before this is due to the fact that the increased water salinity results in the reduction of taxonomic diversity and benthos abundance thus making the indicator taxa methods uninformative.

Table 2. Bioindication indices of macrozoobenthos in lakes of southern Ob-Irtysh interfluve with water salinity more than $3 \mathrm{~g} / \mathrm{dm}^{3}$

\begin{tabular}{llcccc}
\hline Lakes & $\begin{array}{c}\text { H, bit/ind. } \\
\alpha \text {-mesotrophic (by calculations) }\end{array}$ & OI & Bav & Bm \\
\hline Abushkan & 1.1 & 0 & $0.25-\mathrm{b}$ & 1.75 & 2.89 \\
Bol. Topol'noye & 0.9 & 0 & $0.25-\mathrm{b}$ & 1.05 & 3.89 \\
Gor'koye (Kasmala basin) & 1.2 & 0 & $0.4-\mathrm{l}$ & 1.92 & 4.60 \\
Il'uibasor & 1.5 & 0 & $0.25-\mathrm{b}$ & 1.85 & 3.92 \\
Krivoye & 0.5 & 0 & $0.35-\mathrm{l}$ & 0.67 & 2.90 \\
Kulundinskoye & 0.0 & 0 & $0.05-\mathrm{b}$ & 0.25 & 3.91 \\
Presnoye & 0.6 & 0 & $0.15-\mathrm{b}$ & 1.50 & 4.57 \\
Fateyevo (Dushnoye) & 1.1 & 0 & $0.20-\mathrm{b}$ & 0.67 & 3.16 \\
Chebakly & 0.9 & 0 & $0.15-\mathrm{b}$ & 0.35 & 3.91 \\
& \multicolumn{3}{l}{-mesotrophic (by calculations) } & & \\
\hline Gor'koye (Prichanovsk group) & 1.2 & 0 & $0.20-\mathrm{b}$ & 5.40 & 7.89 \\
Levoye Pol'anovo & 1.2 & 0 & $0.15-\mathrm{b}$ & 5.14 & 8.48 \\
Liuskino & 0.9 & 0 & $0.10-\mathrm{b}$ & 3.70 & 7.29 \\
\hline
\end{tabular}

Note: $\mathrm{H}$ - is the Shannon index of species diversity; OI - Goodnight and Whitley oligochaeta index (\%); MMIF Multimetric Macroinvertebrate Index Flanders; 1 - low, b - bad, Bav - average values of macrozoobenthos biomass in bottom sediments of a coastal zone; $\mathrm{Bm}$ - a potential biomass in the absence of inhibitory effect of mineralization.

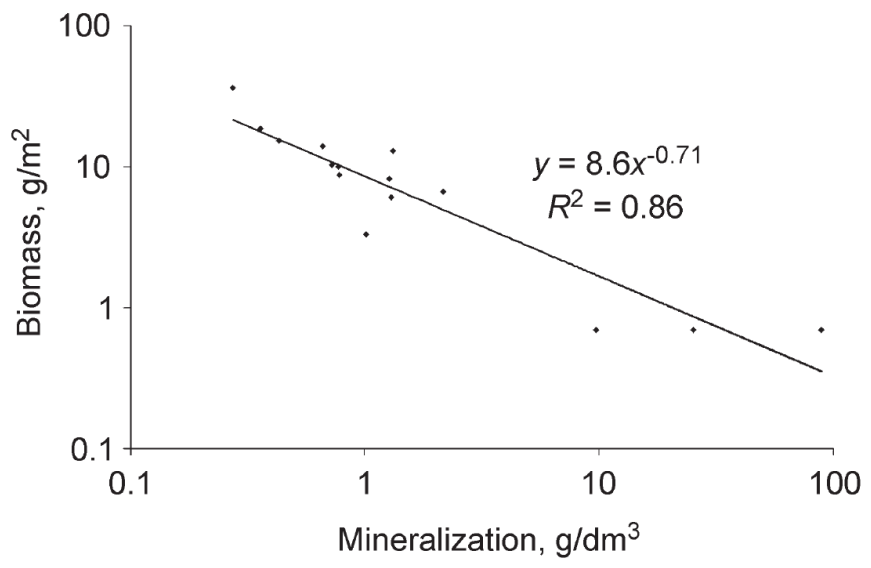

Figure 2. Salinity dependence of macrozoobenthos biomass for the same depths and bottom sediments in coastal zones of lakes of southern Ob-Irtysh interfluve.

The level of zoobenthos development applied in assessing of saline lakes eutrophication is also 
uninformative because any salinity increase results in the increased energy consumption by benthic invertebrates needed for osmoregulation that brings to a decline in the community abundance [26].

To assess the salinity impact on macrozoobenthos biomass, we calculated the dependence (Fig. 2) for widespread slimy bottoms and similar depths in the littoral characterized by strong anthropogenic load from agricultural lands surrounding the lake. The resulting curve is similar to the graph for the lakes of Canada [27] and the Crimea [28] distinguished by a wide data spread because of diverse bottom sediments.

The obtained dependence was approximated as

$$
\mathrm{B}^{\prime}=8.6 \cdot \mathrm{X}^{-0.71},
$$

where $\mathrm{B}^{\prime}$ - is the estimated biomass, $\mathrm{X}$ - is water salinity.

A similar power function with a negative exponent was obtained by A. F. Alimov [29] for the salinity dependence of benthic species number.

Based on the equation (1), we proposed the formula [30] for calculation of potentially lost biomass at salinity increase:

$$
\mathrm{Bp}=\mathrm{B}^{\prime \prime}-\mathrm{B}^{\prime}
$$

where $\mathrm{Bp}$ - is the potentially lost biomass in case of salinity increase, $\mathrm{B} "$ - is the estimated biomass with mineralization of $3 \mathrm{~g} / \mathrm{dm}^{3}$. From equations (1) and (2), we determine the potential biomass value, which could be in the absence of inhibitory effect of mineralization:

$$
\mathrm{Bm}=\mathrm{Bav}+\mathrm{Bp}
$$

where $\mathrm{Bm}$ is the biomass potential in the absence of inhibitory effect of mineralisation, Bav is the average biomass in the foreshore of the reservoir. Using the formula (3), we recalculated benthic macroinvertebrate biomass having regard to the inhibitory effect of mineralization. The calculated data suggest that the majority of lakes are of mesotrophic type. In some lakes, trophic level by chlorophyll a was similar. Hydrochemical studies of these lakes showed high concentrations of biogens $(\mathrm{N}, \mathrm{P})$ in the water [11-13]. Previously, I. V. Baranov [31] also indicated that lakes of the Baraba Lowland are referred to mesotrophic class.

The mentioned approach can be used for indication of other hydrobionts communities and for detection of increase in trophicity (organic pollution) in brackish and salt lakes, but not oligotrophication.

\section{Conclusion}

Standard bioindication methods (i.e. the Shannon index of species diversity (H), Multimetric Macroinvertebrate Index Flanders (MMIF) developed for different-type lakes, and, finally, the Goodnight and Whitley oligochaeta index (Ol), as the additional one) are used for ecological assessment of lakes with water salinity less than $3 \mathrm{~g} / \mathrm{dm}^{3}$. It is necessary to consider the impact of high salt concentrations on hydrobionts communities when making ecological assessment of reservoirs with salinity more than $3 \mathrm{~g} / \mathrm{dm}^{3}$. For the lakes from the same region and of the same mineralization type, one can use the salinity dependence of macrozoobenthos indices at preferably similar depth and bottom sediments with further restoration of indicators of macrozoobenthos development under the absence of inhibitory effect of the increased water salinity.

Acknowledgments. This study was supported by the IWEP SB RAS (project no. 0383-2016-0003) and Russian Foundation for Basic Research (project no. 17-05-00404).

\section{References}

1. A. G. Popolzin, Lakes of the Ob-Irtysh basin (Zonal integrated description). Novosibirsk: South-Sib. Publ., 1967. [in Russian]

2. N. V. Savchenko, Lakes of southern plains in Western Siberia. Novosibirsk, 1997. [in Russian]

3. I. V. Zherelina, D. M. Bezmaternykh, N. V. Stoyashcheva, Materials to the State Report on the state and use of water resources of Altai Krai in 2003. Barnaul: Publ. "Altaina" 2004. [in Russian]

4. Water bodies of Altai Krai, Novosibirsk: Nauka, 1999. [in Russian] 
5. J. Kalff, Limnology: inland water ecosystems. NJ, Upper Saddle River: Prentice-Hall. 2003.

6. D. M. Bezmaternykh, "Water Mineralization Level As a Factor of Zoobenthos Formation in Lakes of the Baraba-Kulunda Limnological Region," Mir Nauki, Kul'tury, Obrazovaniya, 2007, no. 4 (7), pp. 7-11. [in Russian]

7. U. T. Hammer, Saline lake ecosystems of the world. Dordrecht, Dr. W. Junk Publishers, 1986.

8. W. D. Williams, "Salinity as a determinant of the structure of biological communities in salt lakes," Hydrobiologia, vol. 381, pp. 191-201, 1998.

9. G. Wolfram, K. Donabaum, M. Schagerl, and V. Kowarc, "The Zoobenthic Community of Shallow Salt Pans in Austria: Preliminary Results on Phenology and the Impact of Salinity on Benthic Invertebrates," Hydrobiologia, vol. 408/409, pp. 193-202, 1999.

10. L. A. Dolmatova, and A. V. Kotovshchikov, "Assessment of ecological state of lakes of the Novosibirsk region by chemical water composition and pigment characteristics of phytoplankton," Voda: khimiya i ekologiya, 2013, no 7, pp. 28-34. [in Russian]

11. V. V. Kirillov, D. M. Bezmeternykh, Ye. Yu. Zarubina et al., "Composition and structure of ecosystems of steppe lakes of the Altay region in 2008," in Nauka - Altayskomu krayu, 2008. sb. nauch. statey. Vyp. 2. (Science - to the Altay region, 2008. Collected scientific papers. Issue 2.), Barnaul, Azbuka Press, 2008, pp. 237-254. [in Russian]

12. V. V. Kirillov, Ye. Yu. Zarubina, D. M. Bezmeternykh et al. "Comparative analysis of ecosystems of differenttype lakes of the Kasmala and Kulunda valleys of ancient flow," in Nauka - Altayskomu krayu, 2009. sb. nauch. statey. Vyp. 3. (Science - to the Altay region, 2009. Collected scientific papers. Issue 3.), Barnaul, Publishing house of Altay University, 2009, pp. 311-333. [in Russian]

13. V. V. Kirillov, Ye. Yu. Zarubina, A. V. Kotovshchikov et al., "Composition and structure of aquatic ecosystems of the Burla River basin in 2010," in Nauka - Altayskomu krayu, 2010. sb. nauch. statey. Vyp. 4. (Science - to the Altay region, 2010. Collected scientific papers. Issue 4.), Barnaul, Altayskiy Dom Pechati Press, 2010, pp. 239-252. [in Russian]

14. Rukovodstvo po gidrobiologicheskomu monitoringu presnovodnykh ekosistem. (Guidelines on hydrobiological monitoring of freshwater ecosystems). St Petersburg, Gidrometeoizdat Press, 1992. [in Russian]

15. W. Gabriels, K. Lock, N. DePauw et al., "Multimetric Macroinverte-brate Index Flanders (MMIF) for biological assessment of rivers and lakes in Flanders (Belgium)," Limnologica, vol. 40, pp. 199-207, 2010.

16. C. J. Goodnight, L. S. Whitley, "Oligochetes as indicators of pollution", in Proc. 15-th Ind. Waste Conf., Pardue Univ. Ext., Sec. 1961, vol. 106, pp. 139-142.

17. C. E. Shanon, W. Weaver, "The mathematical theory of communication". Urbana, 1963.

18. V. A. Yakovlev, Evaluation of the quality of surface waters of the Kola North by hydrobiological indicators and data biotesting (practical recommendations)", Apatity: Kola branch of the USSR Academy of Sciences, 1988.

19. S. P. Kitayev, "Osnovy limnologii dlia gidrobiologov i ikhtiologov. (Fundamentals of limnology for hydrobiologists and ichthyologists.), Petrozavodsk, 2007. [in Russian]

20. D. M. Bezmaternykh, O. N. Zhukova, "Composition, Structure and Factors of Formation of Communities of Benthic Invertebrates in Lakes of the South of the Ob-Irtysh Interfluve," Russian Journal of Ecology, vol. 44, no 2, pp. 170-177. 2013. DOI: 10.1134/S1067413613020057

21. D. Bezmaternykh, O. Zhukova, "Biodiversity of benthic invertebrates in lakes located along aridity gradient (lakes in the south of West Siberia as a case study)," in Sustainable development of Asian countries, water resources and biodiversity under climate change: Proceedings of AASSA Regional Workshop / Compilation by D.M. Bezmaternykh, D.N. Troshkin; Institute for Water and Environmental Problems, Siberian Branch of the Russian Academy of Sciences (IWEP SB RAS), Barnaul, 2013, pp. 79-82. DOI: 10.13140/2.1.4096.4482

22. O. N. Vdovina, D. M. Bezmaternykh, "Peculiarities of Macrozoobenthos in Lakes of Different Mineralization of the Southern Section of the Ob-Irtysh Interfluve", Hydrobiological Journal, vol. 52, no. 3, pp. 65-73, 2016. DOI: 10.1615/HydrobJ.v52.i3.60

23. D. M. Bezmaternykh, "Spatial and Temporal Organization of Benthic Macroinvertebrate Communities in Lake Chany, Western Siberia," Russian Journal of Ecology, vol. 47, no. 5, pp. 480-485, 2016. DOI: 10.1134/S1067413616050039

24. V. N. Pshenitsyna, "On the efficiency of Woodiwiss scale in bioindication of water quality," Hydrobiological Journal, vol. 24, No. 4, pp. 42-45, 1986. [in Russian] 
25. Yuri I. Vinokurov, A. V. Puzanov, D. M. Bezmaternykh et al. "Modern state of water resources and water economic complex of the Ob-Irtysh basin", Novosibirsk: SB RAS Publ., 2012. [in Russian]

26. V. V. Khlebovich, "Critical salinity and chorohalinicum: modern analysis of concepts," in Biology of brackish and hyperhaline waters, Leningrad: Zoological Institute of the USSR Academy of Sc., 1989, pp. 5-11. [in Russian]

27. U. T-. Hammer, "Distribution and abundance of littoral benthic fauna in Canadian prairie saline lakes," Hydrobiologia, vol. 197, pp. 173-192, 1990.

28. E. V. Balushkina, S. M. Golubkov, M. S. Golubkov et al, "Characteristic features of ecosystems of hyperhaline lakes of the Crimea," Proc. Zool. Inst. Russ. Acad. Sci., 2005, B. 308, pp. 5-12.

29. A. F. Alimov, "Relationship of biological diversity in continental waterbodies and their morphometry and water mineralization", Biology of inland waters, 2008, no 1. pp. 3-8. [in Russian]

30. D. M. Bezmaternykh, O. N. Zhukova, "Method of Evaluating Trophic Status of Ecosystems of Mineralised Lakes on Level of Development of Aquatic Communities", Patent Number RU 2513330 C1, Published: 20 Apr 2014, Bull. no 11. [in Russian]

31. I. V. Baranov, "Limnologicheskiye tipy ozer SSSR. (Limnological types of lakes of the USSR.)", Leningrad, 1962. [in Russian] 